\title{
Zijin Mode: Industry and Education Deep Integration in Mining Engineering
}

\author{
Wanzhong Yin, Weiran Zuo*, Lixian Zhang, Yan Fan \\ College of Zijin Mining, Fuzhou University, Fuzhou, Fujian, China
}

\begin{abstract}
This paper introduced the Industry and Education Deep Integration mode conducted by Fuzhou University in the process of Mining Engineering Education. The specific mode in Fuzhou University is named Zijin Mode, which can be briefed as "the enterprises support the construction of education, the enterprises participate in the education process, and the enterprises test the effectiveness of the education". There are six integrations in the Zijin Mode, i.e. the integration of organization, the integration of experimental platform and teaching resources, the integration of teachers' team, the integration of talent cultivation and use, the integration of teaching and the integration of science and technology innovation and transformation. The deep integration of industry and education in Zijin Mode provided guidance to Mining Engineering Education and worth popularizing.
\end{abstract}

Keywords: mining engineering, education, industry and education integration

\section{Introduction}

In December 2017, The General Office of the State Council of China issued some opinions on the deep integration of industry and education. The opinions pointed out that the promotion of human resources supply-side structural reform has been pressing for the deep integration of industry and education and the organic cohesion between the education chain, talent chain, industry chain and innovation chain. This is of great significance for improving education quality, expanding employment and entrepreneurship, promoting economic transformation and upgrading, cultivating new momentum for economic development across the board under new situations (General Office of the State Council 2017).

Mining Engineering discipline was established in Fuzhou University in March 2007. The idea of industry and education integration was generated at the founding of the discipline. Under the joint initiative of Professor $\mathrm{Wu}$ Minsheng, former president of Fuzhou University, and Mr. Chen Jinghe, board chairman of Zijin Mining Group, College of Zijin Mining was founded in Fuzhou University. The desire to found College of Zijin Mining is to improve the overall practical abilities of Mining Engineering graduates increasingly and to solve the bottle neck of talent cultivation quality, through the support from mining company in terms of the mine site practice platform and the participation of company's professionals into teaching process. Such industry-education integrated teaching mode is named Zijin Mode. The concept of Zijin Mode can be concluded as "the enterprises support the construction of education, the enterprises participate in the education process, and the enterprises test the effectiveness of the education" (Liu et al 2013), as illustrated in Figure 1. The exact mechanism of Zijin Mode will be introduced in section 2.

Up to now the Zijin Mode, as an example of the deep integration of industry and education, has been put into practice for ten years. The integrations in Zijin Mode were reflected in six aspects, i.e. the integration of organization, the integration of experimental platform and teaching resources, the integration of teachers' team, the integration of talent cultivation and use, the integration of teaching and the integration of science and technology innovation and transformation. Experience of these integrations is introduced in this paper to promote the development of Mining Engineering education.

\section{Deep Integration of Industry and Education Mode}

The principal and purpose of the integration of industry and education is to jointly cultivate talents by both university and industry. According to the requirement of industry and regional development, it is necessary to fasten the structure adjustment of talent cultivation, to innovate education organization form and to improve the joint development of education and industry. Based on above understanding, noticeable investigation had been conducted by College of Zijin Mining, Fuzhou University.

\subsection{The integration of organization}

The university and the enterprise set up college council together, to comprehensively guide the college construction and development plan. Fuzhou University appointed four members, and Zijin Mining Group appointed three members

* Corresponding Author: Weiran Zuo, Email: zuoweiran@163.com, phone: +86 13489988094 


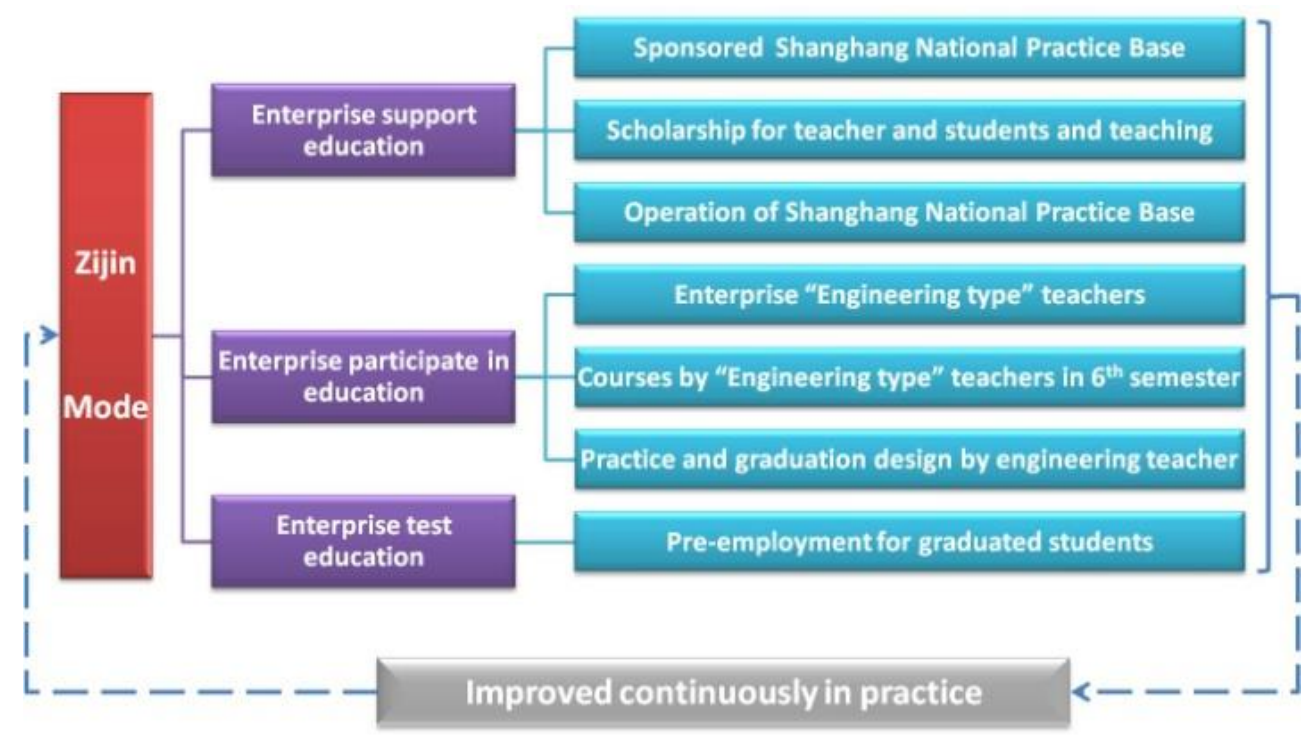

Figure 1 Schematic drawing of Zijin Mode

for the university-enterprise joint council. Board chairman of Zijin Mining Group, Mr. Chen Jinghe was appointed to be the chairman of college council. Generally, Zijin Mining Group appoint two key senior executives to be the council members, while Fuzhou University appoint a vice president, head of Academic Affairs Office and the leaders of the college to be the council members. Governing Council meeting was held twice a year for decision-making, advisory guidance and supervision and coordination for the college discipline construction and development, the discipline settings, the personnel cultivation, the interaction among industry, education and research, the schooling cost and other major issues.

College of Zijin Mining and Zijin Mining Group established a management committee in Shanghang Base to coordinate the construction and management of the teaching base. The management committee consists of Base Administration Office and a teaching steering group comprising members from both the enterprise and the university. The teaching base office established a relatively complete teaching management system, responsible for the day-to-day teaching operation management, logistics base, external communication and coordination, student management, laboratory management, and other transactions.

\subsection{The integration of experimental platform and teaching resources}

In the early period of the college, Zijin Mining Group donated 30 million Yuan to the college for teaching infrastructure construction and talent appointment. The company also provides scholarship to the college for a million Yuan per year. In 2010 Zijin mining group acquired 80 acres of land in Shanghang county, where the headquarter of Zijin Mining Group locates, and invested about 150 million Yuan to build the Shanghang Practice Teaching Base for College of Zijin Mining with complete hardware facilities prepared. The base has complex building, teaching lab building, museum, library, teacher and student apartments, canteens, and sports leisure facilities. After running for these years, rich experience of management and operation and fruitful teaching achievements had been obtained in Shanghang Base. In July 2012, the Shanghang base was approved as National Engineering Practice Education Center (Wang et al 2013).

Zijin Mining Group's subsidiaries, such as Geological Exploration Institute, Mining and Metallurgy Design and Research Institute, Analysis and Testing Company, Geological and Mineral Museum, Mining enterprises and other platforms, are open to college teachers and students. Teachers can use these platforms, resources, equipment to carry out teaching and research work, and students can follow the teachers and enterprise technical staff to carry out experimental activities and research training.

\subsection{The integration of teachers' team}

Talents introduced into College of Zijin Mining enjoy the Fujian Province and Fuzhou University talent introduction policy and enjoy the Zijin Mining Group's donated supporting funds. In recent years the college introduced more than 30 talents from universities, research institutes and industry. To guarantee the implementation of cultivation programme and to improve the students' engineering accomplishment simultaneously, Zijin Mining group select senior engineering professionals in enterprises to participate in teaching activities. The selected professionals will become the engineering-type teachers through pre-job training of the new teacher by Fuzhou University. A series of policies for the selection, employment and management of enterprises engineering-

type teachers were formulated. A teaching operation management mechanism was also built. In the last 4 years, 97 engineering-type teachers were employed to take responsibility of courses teaching and enterprise practice guidance in Shanghang base, which laid a solid foundation 
for the implementation of the cultivation programme (Peng et al 2014a).

\subsection{The integration of talent cultivation and use}

In the talent cultivation process, deep industry-education cooperation was implemented. Zijin Mining Group participated in the design, implementation and management of every talent cultivation program. Students cultivation programme of all majors in the college were designed according to industry demand, based on the requirement of national mining industry standards and enterprise development, with the goal of cultivating severely needed applied talents for geology and mining industry; to improve the college's service capacity and contribution to geology and mining industry of China.

In Zijin Mode, a $3+1$ talent cultivation system (3 years in Campus and 1 year in Shanghang Base) had been developed. The basic course learning is conducted in university for 3 years, and the study in the base enterprise is 1 year in total (Figure 2). This integrated talent cultivation had been implemented successfully in the last ten years. Benefited from the one year training in Shanghang Base, the graduates were cultivated to conform with the standard set up by the Plan for Educating and Training Outstanding Engineers (Peng et al 2014b).

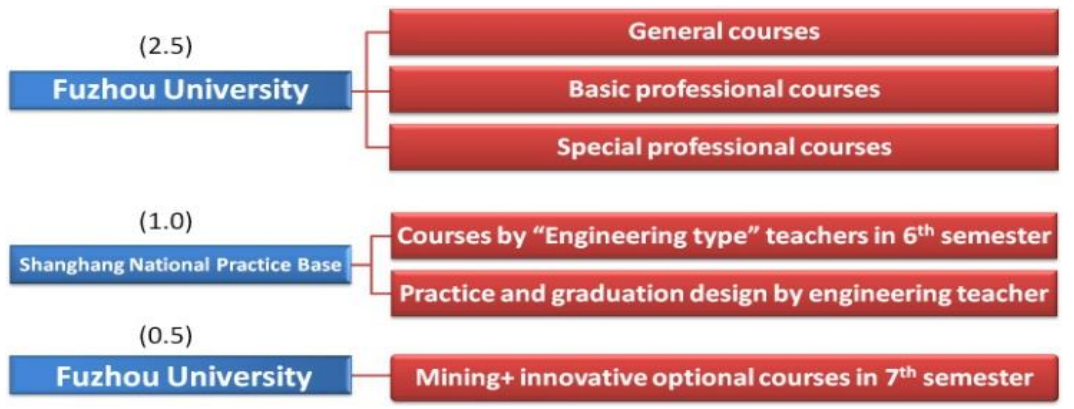

Figure 2 Courses system of Zijin Mode

College of Zijin Mining built a graduated talent database to track the career development of graduates and master the evaluation and suggestions of employers to students' quality in time. A teaching supervision group was established by the university and enterprise collaboratively, to monitor and guide the teaching operation of Shanghang Base and to ensure teaching quality. In addition, through operation and management symposium in Shanghang Base and symposium for enterprises engineering-type teachers, the feasibility and effect of the actual teaching operation of Zijin Mode were understood. Evaluation and recommendations were reported to the Council promptly, as the basis of adjustment of the training program, updating the teaching contents, and improving teaching methods.

\subsection{The integration of teaching}

The integrated cultivation programme of the 3 majors in College of Zijin Mining specified the procedure of enterprise engineering-type teachers' involvement in the process of education, which is mainly reflected in the sixth and the eighth semester of the study. Teaching activities for undergraduates in the sixth semester are conducted in Shanghang Base, including compulsory and optional courses, professional practice and course design, etc., taught by the engineering-type enterprise teachers. The professional courses teaching and practice in the base are sponsored by Zijin Mining group, with an average of 1.5 million Yuan per year.

From 2nd year for undergraduates, the college begin to organize students to sign contract with Zijin Mining Group, which is called Pre-employment Agreement. According to pre-employment status, students are sent to the predetermined subordinate units of Zijin Mining Group to complete graduation design or thesis based on the practical project implemented in the subordinate units. This gives a chance for students to play the role in enterprise in advance and can shorten the future internship. Students can complete the graduation design or thesis under the supervision by both college teacher and engineering professionals from enterprise (Huang et al 2010).

When students are dispatched to the corresponding preemployment enterprise, a college teacher will be determined as his/her supervisor. Each college supervisor is designated to a number of specific mine sites. The supervisor keeps in touch with these mine sites and is familiar with the basic geological background, the mineralization mechanism, the economic benefits and management and the mining and mineral processing features of these mine sites.

\subsection{The integration of science and technology innovation and transformation}

The college aims to take the full advantages of the college teachers in scientific research, actively provide technical services for enterprises, develop industrialization-oriented research results, improve the economic efficiency of enterprises, and achieve the purpose of energy saving and emission reduction. One example is the Fuzhou UniversityZijin Mining Group joint project Study on the Epithermal porphyry Copper and Gold Ore Deep Mineralization Mode and Exploration Technology Demonstration granted by Department of Science and Technology of China, with funding amounted to 60 million Yuan. The project outcome 
Zijinshan Ore Field Mineralization Mode and Exploration Technology Research and Deep Prospecting Application had won the China Gold Association Special Award of Science and Technology in 2014 and the third prize of Science and Technology Progress of Fujian Province. College of Zijin Mining's engineering-type teachers can apply for National Natural Science Fund project through Fuzhou University's platform. This policy not only makes the best of the enterprise technical ability, but also encourages the college teachers to participate in enterpriserelated research projects. This reflects the win-win advantage of the deep integration of industry and education.

\section{Performance of Zijin Mode in Practice}

\subsection{Effect of Zijin Mode}

The first-time employment rate of College of Zijin Mining in the past three years was as high as 98\%, with postgraduate program enrollment rate being $20 \%$. The tracking survey of the college graduates showed that their employers are of high satisfaction with them. For example, in the investigation of the quality of graduates in 2014, 31.3\% of employers said they were very satisfied with the college's graduates, $68.7 \%$ of employers said that they were satisfied and there were no dissatisfaction reaction. The employers generally think that college graduates are with high quality, dedication, learning ability, practical ability and professional skills. The 2011 graduate, Zhang Junyang, majored in resources exploration, achieved percentage of positive drillhole as high as $80 \%$ in Xinjiang Ashele copper mine periphery exploration project, and won the 2014 Zijin Mining Group First Prize. 2012 graduate, Dai Shuiping, majored in mining engineering, had been promoted to department director of Wuping Zijin company within just 2 years, because of his excellent performance. He also won 2014 Zijin Mining Group third prize.

\subsection{Innovations of Zijin Mode}

First, Zijin Mode of deep integration of industry and education was created and operated successfully. The concept of Zijin Mode can be concluded as "the enterprises support the construction of education, the enterprises participate in the education process, and the enterprises test the effectiveness of the education".

Secondly, the Shanghang practice teaching base is the first example for engineering universities in China as an independent, fully equipped practice teaching base invested and built by enterprise. This cast a model to prompt social, enterprise and personals to sponsor education work.

Thirdly, College of Zijin Mining created a system for the selection, appointment and management of enterprise engineering-type teachers and a management mechanism for teaching activities. This enables the enterprise engineering professionals to give full play to their advantages in the practice teaching for Mining Engineering students. As a result, the practice education level and capability of undergraduate students can be improved significantly.
Lastly, College of Zijin Mining created the management methods and operation mechanism for Shanghang National Engineering Practice Education Center, which provide a reference for mining schools and other engineering schools.

\subsection{Exemplary role of Zijin Mode}

After the ten years of running Zijin Mode, the college has achieved fruitful results in teaching reform. The development of Zijin Mode had benefited from Excellent Engineering Education and Training Plan launched by Education Department of China, the Pilot Project of Discipline Comprehensive Reform of China, the Pilot Project of Discipline Comprehensive Reform of Fujian Province and the Brand Discipline Construction Project for 211 High Level University sponsored by Fuzhou University. Zijin Mode had got great attention from the Education Department of China, the Education Department of Fujian Province, and the Department of land and resources of China. Zijin Mode had been presented many times in Excellent Engineer Education Seminar held by Education Department of China, seminars held by China Geological Society, Fujian province Higher Education Seminar and became a model for deep integration of industry and education.

College of Zijin Mining had been visited and consulted by the Committee of Higher Education of Shandong province, Minjiang University, Longyan University and other universities and colleges. In particular, with reference to Zijin Mode's operation and management mechanism and experience, Fuzhou University established Quangang Petrochemical College of Fuzhou University. Consequently, Fuzhou University established Jinjiang Science and education Park in cooperation with the Jinjiang City government, which had become one more highlight of the deep integrated of industry and education.

\section{Conclusion}

Zijin Mode of deep integration of industry and education in Mining Engineering had been created by College of Zijin Mining, Fuzhou University, and got significant achievements. Constructive reform experience had been obtained in terms of the development of National Engineering Practice Education Center and the establishment of enterprise engineering-type teachers team. Zijin Mode is highly coincided with the idea of deep integration of industry and education for present China higher education and is a meaningful investigation for the deepening education supply-side structural reform.

\section{Acknowledgement}

The design and operation of Zijin Mode is made possible through the across-the-board support from Zijin Mining Group. 


\section{References}

General Office of the State Council, 2017. Accelerating the Integration of Industry and Education. China Economic Information, (24): 9p. (In Chinese)

Huang, P., Y. Liu and S. Wang and X. Zhong, 2010. Practice and thinking on the construction, operation and management of Shanghang teaching base under Zijin mode. Chinese Geological Education, 108(7): 42 - 45. (In Chinese)

Liu, Y., P. Huang, X. Peng, S. Wang and Y. Fei, 2013. Implementation and experience of the teaching reform of "Zijin model". Chinese Geological Education, (2): 27-30. (In Chinese)
Peng, X., Y. Liu and D. Li, 2014a. Resources Exploration Engineering enterprise practice and graduation design cooperation double supervisor training mode. Chinese Geological Education, (3): 66 - 68. (In Chinese)

Peng, X., Y. Liu, and D. Li, 2014b. Zijin Mode of Resource Exploration Engineering undergraduate enterprise cultivation program: Framework system and operational mechanism. Chinese Geological Education, (4): 41 - 44. (In Chinese)

Wang, S., Y. Liu, P. Huang, X. Lou and S. Liu, 2013. Relying on state-level project practice education center to construct enterprise double-type teachers team. Chinese Geological Education, (2): 64 - 67. (In Chinese) 